\title{
Responsibilities of Financial Technology Company Due To Failure to Pay By Loan Recipients
}

\author{
Sylvia Janisriwati
}

Faculty of Law Universitas, Surabaya. E-mail: janisriwati@gmail.com

\section{Article Info \\ Keywords: \\ Responsibility; Financial \\ Technology; Default. \\ How to cite (APA Citation Style): \\ Janisriwati, S. (2021). \\ "Responsibilities of \\ Financial Technology Company Due to Failure to Pay by Loan Recipients". Jambura Law Review. JALREV 3 (2): 198-213}

(c) 2021 - Janisriwati, $S$

Under the license CC BY-SA 4.0

\begin{abstract}
One form of business is due to current developments in financial technology (abbreviated as fintech), which means using technology to provide financial solutions. This study aims to see the responsibility of PT. Dana Agung Nusantara as the financial technology (fintech) lending provider due to default by lending recipients in the case of Central Jakarta Commercial Court Decision Number 113/Pdt.Sus-PKPU/2021/PN Jkt.Pst. This research is normative juridical research. In this study, the source of legal materials used consisted of 3 (three) legal materials, namely primary, secondary and tertiary legal materials. The technique of collecting data on legal materials is by using a literature study model using analysis of legal materials, which is used in descriptive qualitative content analysis. The results showed that the responsibility of PT. Dana Agung Nusantara as the financial technology (fintech) lending provider due to default by loan recipients by the case of Central Jakarta Commercial Court Decision Number 113/Pdt.SusPKPU/2021/PN Jkt.Pst that according to an OJK spokesperson, the party is responsible if The fintech collapsed is a P2P lending fintech provider. Meanwhile, if the borrower causes a default, it is the responsibility of the lender or investor.
\end{abstract}

\section{Introduction}

Globalization is a necessity that cannot be avoided by any nation and country because of the rapid flow of information and reaching an extensive and borderless area. ${ }^{1}$ These

\footnotetext{
${ }^{1}$ E. Saefullah Wiradipradja. (2012). "Dampak Negatif Globalisasi Terhadap Persatuan Dan Kesatuan Bangsa Indonesia Dan Strategi Menghadapinya", dalam An An Chandrawulan et al, "Kompilasi Hukum Bisnis Dalam Rangka Purnabakti Prof. Dr. H. Man Sastrawidjaja. S.H., S.U.,”. Bandung: CV. Keni. p. 55.
} 
developments were created in line with human needs, which is to make life easier. ${ }^{2}$ Moreover, information technology has changed the ways of transacting and opening up new opportunities in business transactions. ${ }^{3}$ One form of business resulting from these developments in financial technology (abbreviated as fintech) means using technology to provide financial solutions.

According to The National Digital Research Center (NDRC), fintech is an innovation in the financial sector. Thus, this financial innovation gets a touch of modern technology. The existence of fintech can bring about a more practical and secure financial transaction process. ${ }^{4}$ Fintech is the implementation and use of technology to improve banking and financial services, generally carried out by startup companies by utilizing the latest software, internet, communication, and computing technologies. ${ }^{5}$

The parties in this P2P Lending-based fintech service consist of information technology-based lending and borrowing service providers, lenders, and lending recipients. In this case, the researcher limits the borrower to an individual borrower, not a legal entity borrower. This is also regulated in Regulation of the Financial Services Authority Number 77/POJK.01/2016. ${ }^{6}$ The mechanism is that the system from the fintech operator will bring together the borrower and the party providing the lending. Therefore, it can be said that P2P Lending-based fintech services are a marketplace for online lending and borrowing activities.

\footnotetext{
2 Hikmahanto Juwana. (2002). “Bunga Rampai Hukum Ekonomi Dan Hukum Internasional”. Tangerang: Lentera Hati. p. 23.

3 Haris Faulidi Asnawi. (2004). "Transaksi Bisnis E-Commerce Perspektif Islam”. Yogyakarta: Magistra Insania Press. p. 42.

4 Fauziah Hadi. "Penerapan Financial Technology (Fintech) sebagai Inovasi Pengembangan Keuangan Digital di Indonesia". Retrieved from http://temilnas16.forsebi.org/penerapanfinancial-technologyfintech-sebagai-inovasi-pengembangan-keuangan-digital-di-indonesia . Accessed on May 19, 2021.

5 Nofie Iman. (2016). "Financial Technology dan Lembaga Keuangan". Yogyakarta: Gathering Mitra Linkage Bank Syariah Mandiri. p.6.

${ }^{6}$ Article 1 Number 6, Number 7, and Number 8 0JK Regulation Number 77/P0JK.01/2016.
} 
The development of $\mathrm{P} 2 \mathrm{P}$ lending fintech companies as providers of information technology-based financial services has encouraged the Financial Services Authority (abbreviated as $0 \mathrm{JK}$ ) as the regulator and supervisor of activities in the financial services sector to form Financial Services Authority Regulation (abbreviated as POJK) Number 77/POJK.01/2016 concerning Services Information Technology-based Borrowing and Money Lending. This POJK is a special rule that regulates and requires P2P fintech companies to register to OJK to have a license to operate according to the provisions of Article 7 of the POJK. As of February 2019, OJK recorded that the number of registered and licensed fintech P2P lending providers was 99 companies. ${ }^{7}$

POJK is expected to protect consumer interests in accessing online money lending services issued by P2P lending fintech companies. Unfortunately, the POJK has not been able to reach the interests of legal protection for lenders or online platforms in the event of default or lousy credit. ${ }^{8}$ In addition, regulations are needed to regulate legal mechanisms if the lending recipient fails to pay or does not fulfill their obligations on time. This regulation is essential considering the development of online lending business providers in Indonesia has been developed.

This is appropriate in the case of PT. Dana Agung Nusantara is the provider of financial technology (fintech) lending due to a default in the Court of Central Jakarta Commercial Court Number 113/Pdt.Sus-PKPU/2021/PN Jkt.Pst. The Central Jakarta Commercial Court rejected PT. Ayers Asset Management against PT Dana Agung Nusantara as the financial technology provider (fintech) related to a lending case worth Rp 1.5 billion. In this decision, the Panel of Judges stated that PT. Dana Agung Nusantara is the

\footnotetext{
7 Otoritas Jasa Keuangan, "Penyelenggara Fintech Terdaftar di OJK Per 1 Februari 2019", accessed on May 19, 2021.

8 Heryucha Romanna Tampubolon. (2019). “Seluk-Beluk Peer to peer lending Sebagai Wujud Baru Keuangan Di Indonesia". Jurnal Bina Mulia Hukum, 3 (2): 196.
} 
provider of the lending, not the recipient of the lending. Thus, it cannot be sued. ${ }^{9}$

According to PT Dana Agung Nusantara's attorney, in the three-party cooperation agreement between the lender, lending recipient, and lending provider, it has also been regulated in detail that the lending provider, in this case, is PT. Dana Agung Nusantara has no obligation to compensate if a default case arises. ${ }^{10}$

Based on this description, there is still confusion as to who has the responsibility related to the default by the loan recipient. In this case, therefore, the author is interested in studying deeply related to the responsibility of PT. Dana Agung Nusantara as the financial technology (fintech) lending provider due to default by lending recipient at Central Jakarta Commercial Court Decision Number 113/Pdt.SusPKPU/2021/PN Jkt.Pst.

\section{Problem Statement}

Based on the description above, the researchers raise the legal issue, which is "how is the responsibility of PT. Dana Agung Nusantara as the financial technology (fintech) lending provider due to default by the lending recipient in the Central Jakarta Commercial Court Decision Number 113/Pdt.Sus-PKPU/2021/PN Jkt.Pst?"

\section{Method/ Approach}

This research is normative juridical research using a statutory and conceptual approach. This research is a normative juridical with a literature approach by studying journals, books, legislation, and other documents related to this research. Normative law is directly related to law practice, which involves two main aspects, namely the formation of law and the application of the law. ${ }^{11}$ This approach views law as

\footnotetext{
${ }^{9}$ Siprianus, Edi Hardum, (2021), "Kasus Fintech, PN Jakpus Tolak Gugatan PT Ayers terhadap PT Dana Agung Nusantara". Retrieved from https://www.beritasatu.com/nasional/759419/kasus-fintech-pnjakpus-tolak-gugatan-pt-ayers-terhadap-pt-dana-agung-nusantara . Accessed on May 19, 2021.

10 Ibid.

${ }^{11}$ Rusli, Hardijan. (2006). “Metode Penelitian Hukum Normatif: Bagaimana?”, Law Review 5 (3): 50.
} 
synonymous with written norms made and promulgated by official institutions or officials.

There are 3 (three) legal materials in this study: primary, secondary, and tertiary. Primary legal materials are provisions relating to the liability of PT. Dana Agung Nusantara is the financial technology (fintech) lending provider due to default by the lending recipient. Secondary legal materials are all publications on the law that are not considered official documents (books, dictionaries, journals, and court decisions). In contrast, tertiary legal materials are Big Indonesian Language Dictionaries, legal dictionaries, encyclopedias, etc. The technique of collecting legal materials uses a literature study model. ${ }^{12}$

The legal material analysis technique used is the content analysis technique. Content analysis is any systematic procedure that is encouraged to examine the content of the information obtained. This analysis focuses on all the secondary data obtained. After obtaining the necessary data, this paper analyzes the data logically, systematically, and juridically. Logical means that the data collected is analyzed following the principles of deductive logic, namely, concluding a general problem to the concrete problems faced-systematic means analyzing data by linking data with one another that are interconnected and dependent. Furthermore, the data were analyzed juridically, starting from the existing regulations and related to the positive law currently in effect.

\section{Discussion}

\subsection{Regulations Regarding Fintech-Based Online Lending Services}

The development of information technology brings a new era of human civilization, which is now popularly called Industry 4.0 , where also changes the patterns and lifestyles of people who are now done entirely online or internet-based, starting from shopping. One form of business resulting from these developments is a financial

12 Ibrahim, Jhonny. (2006). "Teori dan Metodologi Penelitian Hukum Normatif”. Malang: Banyumedia Publishing. 
technology (abbreviated as fintech), which provides financial solutions. ${ }^{13}$

Fintech-based financial services, which are widely used by the public, are online lending funds that provide easy and fast access to public lending and applications, as well as various applicants who offer to lend to the public. Thus, it is tempting to the public, and many people are interested in using Fintech-based cash lending services.

The development of the Fintech-based money and credit sector, of course, requires regulators and the Indonesian government to be prepared to deal with it, especially in the areas of institutions, business operations, and risk mitigation. ${ }^{14}$ Regarding the implementation of the Fintech industry in Indonesia, several regulations regulate, which are:

a. Regulation of the Financial Services Authority (POJK)

First of all, OJK has issued OJK Regulation (POJK) Number 77/ POJK.01/2016 concerning Information Technology-Based Lending and Borrowing Services (POJK Fintech P2PL), which then has a derivative regulation in the form of OJK Circular Letter (SEOJK) number 18/ SEOJK. 02/2017.

This POJK regulates one type of fintech currently developing in Indonesia, called Peer Peer Lending (P2PL Fintech). OJK sees the urgency of the presence of provisions governing Fintech lending and borrowing, paying attention to the strong culture of lending and borrowing (debt) in Indonesian society. In addition, the Fintech provider company with the Peer to Peer Lending scheme is the scope of the OJK's authority because the company provides financial services. However, the company does not yet have an institutional, legal basis for its business activities.

Based on the POJK, the P2PL Fintech company, or organizer, is declared as another

\footnotetext{
${ }^{13}$ Douglas W. Arner, Jànos Barberis, Ross P. Buckley. (2016). "The Evolution of FinTech: A New PostCrisis Paradigm?", Jurnal The University Of Hongkong: 3.

14 Sarwin Kiko Napitupulu,dkk. (2017). "Kajian Perlindungan Konsumen Sektor Jasa Keuangan: Perlindungan Konsumen Pada Fintech". Jakarta: Departemen Perlindungan Konsumen - Otoritas Jasa Keuangan. P. 48.
} 
Financial Services Institution with a company in the form of a limited liability company and cooperative (Article 2 Paragraph (2). Business activities that the provider can carry out are in the form of providing, managing, and operating Information Technology-Based Borrowing-Lending Services from the lender to the borrower whose source of funds comes from the lender and/ or the provider may cooperate with the provider of financial-based services. The information technology is following the provisions of the legislation (Article 5). The limit for granting lending to lending recipients is set at IDR 2,000,000,000.00 (two billion rupiahs) (Article 6). ${ }^{15}$

Specifically related to aspects of consumer protection in the financial services sector, OJK has regulations, including: ${ }^{16}$

1) POJK Number 1/POJK.07/2013 concerning Consumer Protection in the Financial Services Sector. This provision especially applies to Financial Services Businesses supervised by the OJK and carries out Fintech services. The PUJK must pay attention to all aspects of consumer protection by applying the principles as stipulated in Article 2, namely the principles of transparency, fair treatment, reliability, confidentiality, and security of consumer data/information, and handling complaints and resolving consumer disputes in a simple, fast, and cost-effective, and affordable manner.

2) POJK Number 77/POJK.01/2016 concerning Information Technology-Based Lending and Borrowing Services and SEOJK Number 18/SEOJK.02/2017 concerning Governance and Information Technology Risk Management in Information Technology-Based Lending and Borrowing Services.

3) SEOJK Number 18/SEOJK.02/2017 concerning Governance and Risk Management of Information Technology in Information Technology-Based Lending and Borrowing Services.

15 Otoritas Jasa Keuangan. Retrieved from https://www.ojk.go.id/id/Pages/FAQ-OtoritasJasaKeuangan. Accessed on April 29, 2020.

16 Sarwin Kiko Napitupulu,dkk, Op.cit. p. 58. 


\section{b. Financial Services Authority Circular (SEOJK)}

After the enactment of POJK Number 77/POJK.01/2016 concerning Information Technology-Based Lending and Borrowing Services, OJK has issued regulations regarding the implementation of information technology governance and risk management in technology-based lending and borrowing services in SEOJK Number 18/SEOJK.02/2017, which comes into force on the date of stipulation, on April 18, 2017. The scope of the regulation includes:

1) Placement of data center and disaster recovery and disaster recovery plan

2) Electronic System and Information Technology Governance which includes Electronic System Strategic Plan, Human Resources, and Information Technology Change Management

3) Technology Transfer

4) Data and Information Management

5) Information Technology Risk Management

6) Electronic System Security

7) Incident Handling and Resistance to Disruption

8) Use of Electronic Signature

9) Service Availability and Transaction Failure

10)Product and Service Information Disclosure

c. Law Number 19 of 2016 amendments to Law Number 11 of 2008 concerning Information and Electronic Transactions

The Electronic Transaction Information Act requires companies that operate electronic systems to operate the system reliably and are responsible for the correct operation of the electronic system. One of the users regulated by the TEC law is the protection of personal information. ITE law requires the use of electronic media containing any personal information with the consent of the individual.

d. Regulation of the Minister of Communication and Information of the Republic of Indonesia Number 4 of 2016 concerning Information Security Management System 
This Ministerial Regulation regulates the information security management system by limiting the requirements used in the regulation. The essential ingredients contain categories: Electronic systems; Information security management system standards; Provide electronic systems; Information security management system certificate; Certification bodies; Issuance of certificates; Report certification results; certificate revocation; Independent trainer evaluation; Control; and Financial Supply.

e. Regulation of the Minister of Communication and Information of the Republic of Indonesia Number 20 of 2016 concerning Personal Data Protection

This Ministerial Regulation regulates the protection of personal information in the electronic system by setting limits on the provisions used in the regulations. Protection of personal information in electronic systems protects the acquisition, collection, processing, analysis, storage, display, disclosure, transmission, distribution, and destruction of personal information. The collection of personal information, processing and analysis of personal information, storage, display, transmission, dissemination of personal information, and/or the acquisition, disclosure, and destruction of personal information will be governed by Chapter II Protection. In addition, this ministerial regulation regulates the rights of personal data holders; Customer responsibility; The role of electronic system service providers; Dispute resolution; State and social responsibility; Control; and Administrative Sanctions. ${ }^{17}$

\subsection{Dispute Settlement Due to Default of Financial Technology (Fintech) Lending Providers}

Implementing P2PL-based fintech that does not run according to the agreement will cause disputes for users of these services. The resolution of these problems can be resolved through specific mechanisms. Disputes can be resolved immediately through the party who feels aggrieved can file a complaint. The existence of non-compliance with the contents in the agreement that the parties have agreed upon is one of the reasons for the occurrence of a dispute. Paths in dispute resolution can be passed through litigation (court) and non-litigation (outside court) channels. Settlement of

17 Ibid., page 62-63. 
disputes by litigation is done by submitting a civil claim through court THAT takes a long time becausE decision at first instance (district court) can still be appealed to the court high to appeal to the supreme court. While the non-litigation settlement (out of court) can be reached using APS through negotiation, opinion binding, mediation, conciliation, adjudication, and arbitration.

The party experiencing the loss can resolve the dispute in an initial way, namely submitting a complaint. Fintech platform operators can follow up on complaints submitted by service users. Settlement of disputes is the goal of the organizers. Besides, it also protects consumers. The scope of complaint services includes receiving complaints, handling complaints, and resolving complaints. ${ }^{18}$

The ways that can be taken to file a complaint include:

a. verbally by telephone letter (email or short message, and/or

b. in writing by), facsimile, or page (website).

Financial service actors must do several things, namely the organizer after the complaint stage from the party experiencing losses, in accordance with the provisions of Article 38 P0JK No.1/P0JK.07/2013:

a. Internal examination of complaints in a competent, correct, and objective manner;

b. Conduct analysis to ensure the truth of the complaint;

c. Submit a statement of apology and offer compensation (redress/remedy) or repair of products and or services if consumer complaints are valid.

The same thing is also regulated in POJK Number 18/POJK.07/2018 concerning Consumer Complaint Services in the Financial Services Sector, which regulates mechanisms related to consumer handling as follows:

a. Complaints from consumers and/or their representatives must be followed up

18 Novita, W. S., \& Imanullah, M. N. “Aspek Hukum Peer To Peer Lending (Identifikasi Permasalahan Hukum dan Mekanisme Penyelesaian)”. Jurnal Privat Law, 8(1): 151-157. 
with competent, correct, and objective internal examination and analysis. Thus, the truth of the complaint can be ascertained (Article 14);

b. If the complaint is made verbally, the financial services business actor is obliged to follow up and complete a maximum of 5 working days from the receipt of the complaint (Article 15);

Meanwhile, suppose the complaint is made in writing. In that case, the financial services business actor is obliged to follow up and complete a maximum of 20 working days from when the relevant documents are received in full (Article 20).

\subsection{Accountability of PT. Dana Agung Nusantara as the Financial Technology} (Fintech) Lending Provider Due to Defaults by Lending Recipients in Central Jakarta Commercial Court Decision Case Number 113/Pdt.Sus-PKPU/2021/PN Jkt.Pst

Fintech is included in renewal activities in business processes, models, and financial instruments that provide new value in the financial services sector. ${ }^{19}$ Businesses or services in the financial sector have become a business that is very vulnerable to various actions that harm irresponsible parties by using the existence of technology to act, be it fraud or abuse that result in losses for users of the services. ${ }^{20}$

The rapid growth of peer-to-peer (P2P) lending technology companies (fintech) in Indonesia has made the Financial Services Authority (OJK) issued some rules to develop and supervise the digital financing business, including in anticipating the company's collapse or bankruptcy.

This is in accordance with the case at Central Jakarta Commercial Court Number 113/Pdt.Sus-PKPU/2021/PN Jkt.Pst relating to the default case of PT Dana Agung Nusantara as the provider of financial technology (fintech) concerning a lending case of Rp. 1.5 billion against PT. Ayers Asset Management. In its decision, the Panel of

\footnotetext{
${ }^{19}$ Salma, C. R. (2019). "Perlindungan Hukum Terhadap Penerima Pinjaman Dalam Perjanjian Penggunaan Layanan Peer To Peer Lending”. Kumpulan Jurnal Mahasiswa Fakultas Hukum: 7.

${ }^{20}$ Edy Santoso. (2018). "Pengaruh Era GlobalisasiTerhadap Hukum Bisnis di Indonesia”. Jakarta: Prenada Media. P. 129.
} 
Judges rejected the lawsuit from PT. Ayers Asset Management and started PT. Dana Agung Nusantara is the provider of the lending and not the recipient of the lending. Thus, it cannot be sued. ${ }^{21}$

Based on this case, the researchers analyze according to the explanation expressed by the OJK spokesman that the party responsible if the fintech collapses are the P2P lending fintech provider. Provided that the organizer is proven to be negligent in running the business, which is caused by the negligence of the employee, management, or third party on duty for the benefit of the company, This is following OJK Regulation Number 77/POK.01/2016 concerning Information Technology-Based Lending and Borrowing Services, in article 37 stating that the operator must be responsible for user losses arising from errors or negligence of the directors or employees of the organizers. $^{22}$

According to $\mathrm{OJK}, \mathrm{P} 2 \mathrm{P}$ lending platforms in Indonesia are only allowed to act as intermediaries between lenders and lending recipients. This is supported by data from OJK spokesman Sekar Putih Djarot who said this was under OJK Regulation Number 77/POJK.01/2016 concerning Information Technology-Based Borrowing and Borrowing Services, article 43 states, organizers are prohibited from acting as providers and borrowers. ${ }^{23}$ Based on POJK 77 of 2016, the operator's responsibility is only to the user, namely the lender and the lending recipient. Regarding this fintech collapse, OJK anticipates it by selecting strictly which fintech companies operate in

\footnotetext{
${ }^{21}$ Siprianus, Edi Hardum, (2021). "Kasus Fintech, PN Jakpus Tolak Gugatan PT Ayers terhadap PT Dana Agung Nusantara". Retrieved from https://www.beritasatu.com/nasional/759419/kasus-fintech-pnjakpus-tolak-gugatan-pt-ayers-terhaap-pt-dana-agung-nusantara. Aaccessed on May 19, 2021.

22 Wahyu. T. Rahmawati. (2018). "Inilah Pihak Yang Bertanggung Jawab Jika Fintech Kolaps". https://keuangan.kontan.co.id/news/inilah-pihak-yang-bertanggung-jawab-jika-fintech-kolaps, Accessed on May 19, 2021.

${ }^{23}$ Wahyu T. Rahmawati. (2018). “OJK Larang Fintech P2P Lending Sebagai Pemberi Pinjaman". Retrieved from https://keuangan.kontan.co.id/news/ojk-larang-fintech-p2p-lending-sebagai-pemberi-pinjaman, Accessed on August 9, 2021.
} 
Indonesia. They must have a registered and licensed mark by fulfilling their rights and obligations as organizers.

Meanwhile, if there is a default caused by the borrower, it is the full responsibility of the lender or investor. OJK requires organizers to communicate openly regarding credit risk or default. From that risk, investors already know the consequences of becoming a P2P Lending lender, including the risk of loss and default. Therefore, the public is urged to fully understand the rights and obligations of P2P lending services users, especially before agreeing to a lending agreement as a fintech lending investor. However, to anticipate the risk of default, OJK encourages P2P lending fintech companies to cooperate with credit insurance companies, credit guarantees, or pawnshops to guarantee and restructure debt between borrowers and investors. In addition, fintech operators who will register with the OJK must also be members of the relevant fintech association. This is done as a form of layered supervision from the association to its members and OJK supervision of fintech lending providers.

Operators who are unable to continue operational activities are required to complete rights and obligations to users. OJK only ensures the completion of the rights and obligations of the operator to service users. Therefore, the public is advised to carefully understand the risks of becoming a fintech lending service user. ${ }^{24}$

In addition, according to the Director of the Indonesian Fintech Association (Aftech), the organizers must be responsible if they are proven to have violated the law or fraud that caused the company to collapse. As for the default case, according to the Director of the Indonesian Fintech Association, it will be the full responsibility of the investor. The organizer is only authorized to select borrowers based on the level of risk and has the power to collect.25.

\section{Conclusion}

Responsibility of PT. Dana Agung Nusantara as the financial technology (fintech) lending provider due to default by the lending recipient according to Central Jakarta

24 Ibid.

25 Ibid. 
Commercial Court Decision Case Number 113/Pdt.Sus-PKPU/2021/PN Jkt.Pst that according to the OJK spokesperson that the party is responsible if the fintech collapses. It is the P2P lending fintech provider. The provider that the organizer is proven to be negligent in running the business, which is caused by the negligence of the employee, management, or third party on duty for the company's benefit. This is under OJK Regulation Number 77/POK.01/2016 concerning Information Technology-Based Lending and Borrowing Services, in article 37 stating that the operator must be responsible for user losses arising from errors or negligence of the directors or employees of the organizers.

Meanwhile, if the borrower causes a default, it is the full responsibility of the lender or investor. In addition, according to the Director of the Indonesian Fintech Association (Aftech), the organizers must be responsible if they are proven to have violated the law or fraud that caused the company to collapse. As for the default case, according to the Director of the Indonesian Fintech Association, it will be the full responsibility of the investor.

\section{References}

Douglas W. Arner, Jànos Barberis, Ross P. Buckley. (2016). “The Evolution of FinTech: A New Post-Crisis Paradigm?", Jurnal The University Of Hongkong

E. Saefullah Wiradipradja. (2012). Dampak Negatif Globalisasi Terhadap Persatuan Dan Kesatuan Bangsa Indonesia Dan Strategi Menghadapinya, dalam An An Chandrawulan et al, "Kompilasi Hukum Bisnis Dalam Rangka Purnabakti Prof. Dr. H. Man Sastrawidjaja. S.H., S.U.,". Bandung: CV. Keni

Edy Santoso. (2018). Pengaruh Era GlobalisasiTerhadap Hukum Bisnis di Indonesia, Jakarta: Prenada Media.

Fauziah Hadi, Penerapan Financial Technology (Fintech) sebagai Inovasi Pengembangan Keuangan Digital di Indonesia, terdapat dalam http://temilnas16.forsebi.org/penerapan financial-technology-fintech-sebagaiinovasi-pengembangan-keuangan-digital-di-indonesia.

Haris Faulidi Asnawi. (2004). "Transaksi Bisnis E-Commerce Perspektif Islam”. Yogyakarta: Magistra Insania Press

Heryucha Romanna Tampubolon. (2019). "Seluk-Beluk Peer to peer lending Sebagai Wujud Baru Keuangan Di Indonesia”. Jurnal Bina Mulia Hukum, 3 (2).

Hikmahanto Juwana. (2002). Bunga Rampai Hukum Ekonomi Dan Hukum Internasional. Tangerang: Lentera Hati

Ibrahim, Jhonny. (2006). Teori dan Metodologi Penelitian Hukum Normatif. Malang: Banyumedia Publishing. 
Nofie Iman. (2016). Financial Technology dan Lembaga Keuangan. Yogyakarta: Gathering Mitra Linkage Bank Syariah Mandiri

Novita, W. S., \& Imanullah, M. N. Aspek Hukum Peer To Peer Lending (Identifikasi Permasalahan Hukum dan Mekanisme Penyelesaian). Jurnal Privat Law, 8(1).

Otoritas Jasa Keuangan. “Penyelenggara Fintech Terdaftar di OJK Per 1 Februari 2019".

Retrieved from https://www.ojk.go.id/id/Pages/FAQ-Otoritas-JasaKeuangan .aspx.

POJK Nomor 77/POJK.01/2016 on Information Technology-Based Lending Services.

Rusli, Hardijan . (2006). Metode Penelitian Hukum Normatif: Bagaimana?. Law Review 5 (3).

Salma, C. R. (2019). Perlindungan Hukum Terhadap Penerima Pinjaman Dalam Perjanjian Penggunaan Layanan Peer To Peert Lending. Kumpulan Jurnal Mahasiswa Fakultas Hukum.

Sarwin Kiko Napitupulu,dkk. (2017). Kajian Perlindungan Konsumen Sektor Jasa Keuangan: Perlindungan Konsumen Pada Fintech. Jakarta: Departemen Perlindungan Konsumen Otoritas Jasa Keuangan

Siprianus, Edi Hardum, (2021), Kasus Fintech, PN Jakpus Tolak Gugatan PT Ayers terhadap PT Dana Agung Nusantara, https://www.beritasatu.com/nasional/759419/kasusfintech-pn-jakpus-tolak-gugatan-pt-ayers-terhadap-pt-dana-agung-nusantara.

Wahyu. T. Rahmawati. (2018). Inilah Pihak Yang Bertanggung Jawab Jika Fintech Kolaps. https://keuangan.kontan.co.id/news/inilah-pihak-yang-bertanggung-jawab-jikafintech-kolaps. 